\title{
Modeling the evolution of loess-covered landforms in the Loess Plateau of China using a DEM of underground bedrock surface
}

\author{
Li-Yang Xiong a, Guo-An Tang a,*, Fa-Yuan Li ${ }^{\mathrm{a}}$, Bao-Yin Yuan ${ }^{\mathrm{b}}$, Zhong-Chen $\mathrm{Lu}^{\mathrm{c}}$ \\ a Key Laboratory of Virtual Geographic Environment, Ministry of Education, Nanjing Normal University, Nanjing 210023, China \\ b Institute of Geology and Geophysics, Chinese Academy of Sciences, Beijing 100029, China \\ ${ }^{\mathrm{c}}$ Research Center for Eco-Environmental Sciences, Chinese Academy of Sciences, Beijing 100085, China
}

\section{A R T I C L E I N F O}

\section{Article history:}

Received 15 April 2013

Received in revised form 28 November 2013

Accepted 2 December 2013

Available online 17 December 2013

\section{Keywords:}

Underlying paleotopography

Landscape evolution

Loess thickness

DEM

\begin{abstract}
A B S T R A C T
The evolution of loess-covered landforms is largely controlled by the pre-Quaternary underlying bedrock terrain, which is one of the most important factors in understanding the formation mechanism of the landforms. This study used multiple data sources to detect 1729 outcropping points of underlying terrain, in order to construct a digital elevation model (DEM) of the paleotopography of an area of the Loess Plateau subject to severe soil erosion. Four terrain characteristics, including terrain texture, slope gradient, the hypsometric curve, and slope aspect, were used to quantify topographic differences and reveal the loess-deposition process during the Quaternary. A loess thickness map was then created to show the spatial distribution of loess deposits in the test area. Finally, the geomorphological inheritance characteristics of the loess-covered landforms were evaluated in different landform divisions. The results showed the significant inheritance of modern topography from the underlying topography with a similar general relief trends. The average thickness of loess deposits was computed to be $104.6 \mathrm{~m}$, with the thickest part located in the Xifeng loess tableland area. In addition, the slope aspects of the North and Northwest seem to have favored Quaternary loess deposition, which supported the hypothesis of an eolian origin for loess in China. The modern surface has lower topographic relief compared to the underlying terrain due to loess deposition.
\end{abstract}

Crown Copyright @ 2013 Published by Elsevier B.V. All rights reserved.

\section{Introduction}

The landforms of the Chinese Loess Plateau have been formed through the eolian transport and accumulation of loess deposits on bedrock during the Quaternary (Liu, 1985). This unique formation mechanism and resultant landscapes attract global attention in relation to their history connected to global change, thick loess sediments, various landscape types, severe soil erosion, and the interaction between natural and human activities. Hence, studying the paleotopography below loess and its impact on the current landform is critical to understand the formation mechanisms and evolution of the Loess Plateau.

Previous studies have developed a wealth of landscape evolution models or methods to numerically represent landscapes and their evolution, such as SIBERIA (Willgoose et al., 1991), GOLEM (Tucker and Slingerland, 1994), CASCADE (Braun and Sambridge, 1997), CAESAR (Coulthard et al., 2000), CHILD (Tucker et al., 2000), ULTIMA THULE (Kaufmann and Romanov, 2012), PECUBE (Braun et al., 2012), CASQUS (Maniatis et al., 2009), the parallel method (Braun and Willett, 2013), the TIN-based method (Refice et al., 2012), the phenomenological method (Dymond and Rose, 2011), and the global flow path search method (Paik, 2012). Such landscape evolution models have been used

\footnotetext{
* Corresponding author. Tel.: + 8613776623891.

E-mail address: tangguoan@njnu.edu.cn (G.-A. Tang).
}

for different landforms to test the capability of the models (Perron et al., 2009; Bowman et al., 2010; Berthling and Etzelmüller, 2011; Fujioka and Chappell, 2011; Temme et al., 2011; Ciampalini et al., 2012; Egholm et al., 2012; Lehmkuhl et al., 2012; Ravazzi et al., 2013). The application of landscape evolution models in relation to climate change (Temme et al., 2009), soil hydraulic properties (Beerten et al., 2012), and natural landslide disasters (Hsieh et al., 2012) has also been discussed from different viewpoints. However, the effect of the original underlying surface, before the modern landscape evolved, has for the most part been ignored in modeling landform evolution. The landforms in the Loess Plateau of China have been formed under a tectonically stable condition of the Ordos platform during the Quaternary (Liu, 1985; Liu et al., 2001), where the morphology and distribution of the underlying paleotopography may have significantly affected the process of landscape formation and evolution. Since the 1950s, much attention has been paid to loess landforms from geological and geomorphological viewpoints. Some scholars investigated the regional variation of soil erosion and the stages of geomorphological developmental of landforms in the Loess Plateau (Stolte et al., 2003; Xu et al., 2004; Cheng et al., 2007; Chen et al., 2008; Zheng et al., 2008; Chen et al., 2010; Hughes et al., 2010; Liu and Liu, 2010; Fu et al., 2011; Zhu, 2012; Xiong et al., 2013). Liu (1985) investigated profiles of loess deposits for the three typical landforms in the Loess Plateau (hill, ridge, and tableland), and found that the sedimentary environment of loess deposits, including the underlying 


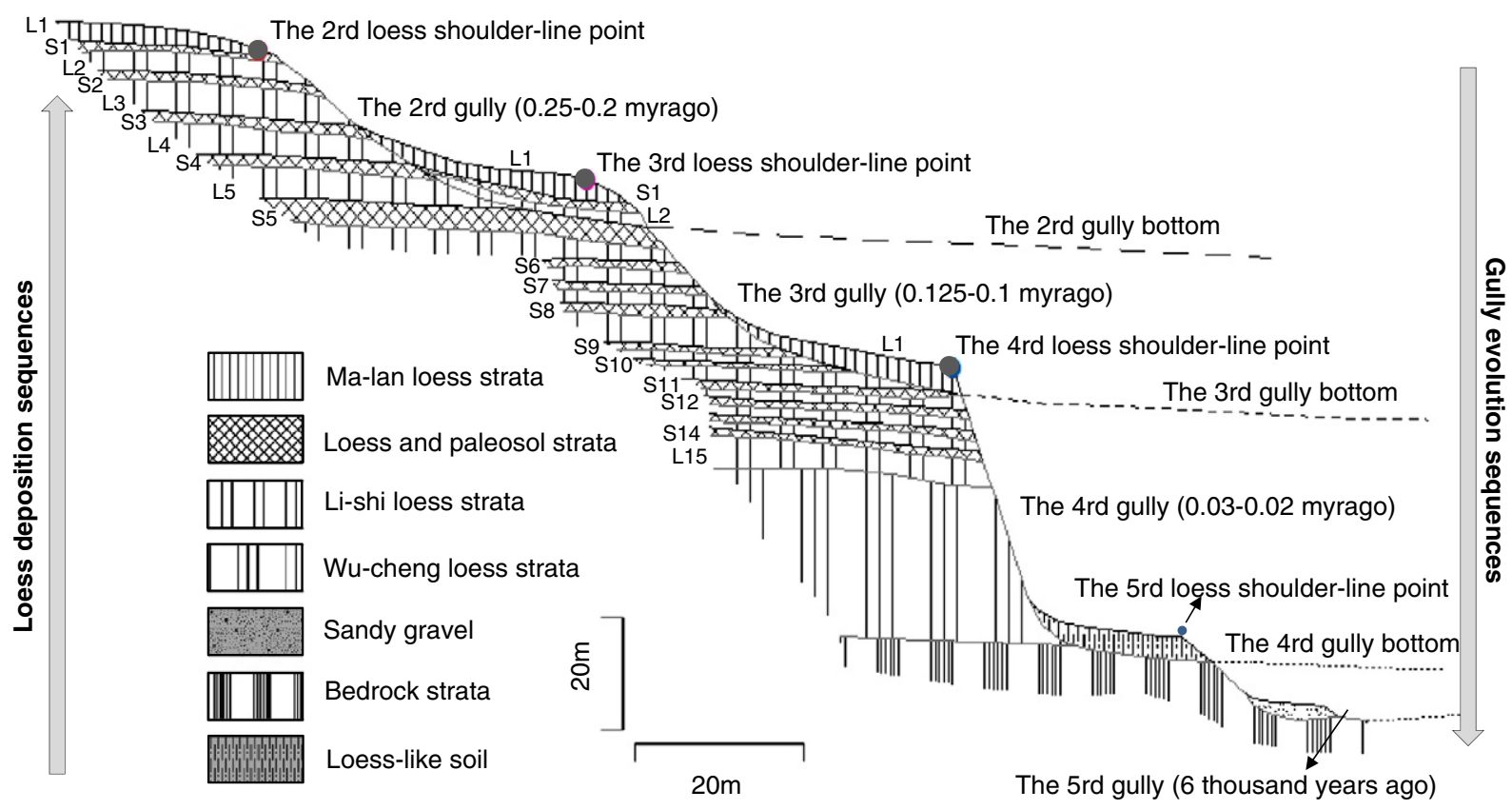

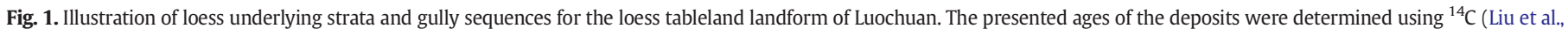
2001). The location of Luochuan is shown in Fig. 2.

bedrock paleotopography, has been related to climate change. This finding deepens the understanding of loess deposition and evolution during the Quaternary. Liu et al. (2001) also indicate that the underlying strata of loess-covered landforms, including the Ma-lan, Li-shi, Wu-cheng loess strata and bedrock (Liu, 1985), should be taken into account in modeling landscape evolution. Fig. 1 shows the relationship of these underlying strata investigated in the typical loess tableland landform of Luochuan in the study area. These existing underlying strata represent different time nodes during the evolutionary process, meaning that without these underlying strata, current proposed landscape evolution models might be incapable of correctly representing the evolution of the loess landform.

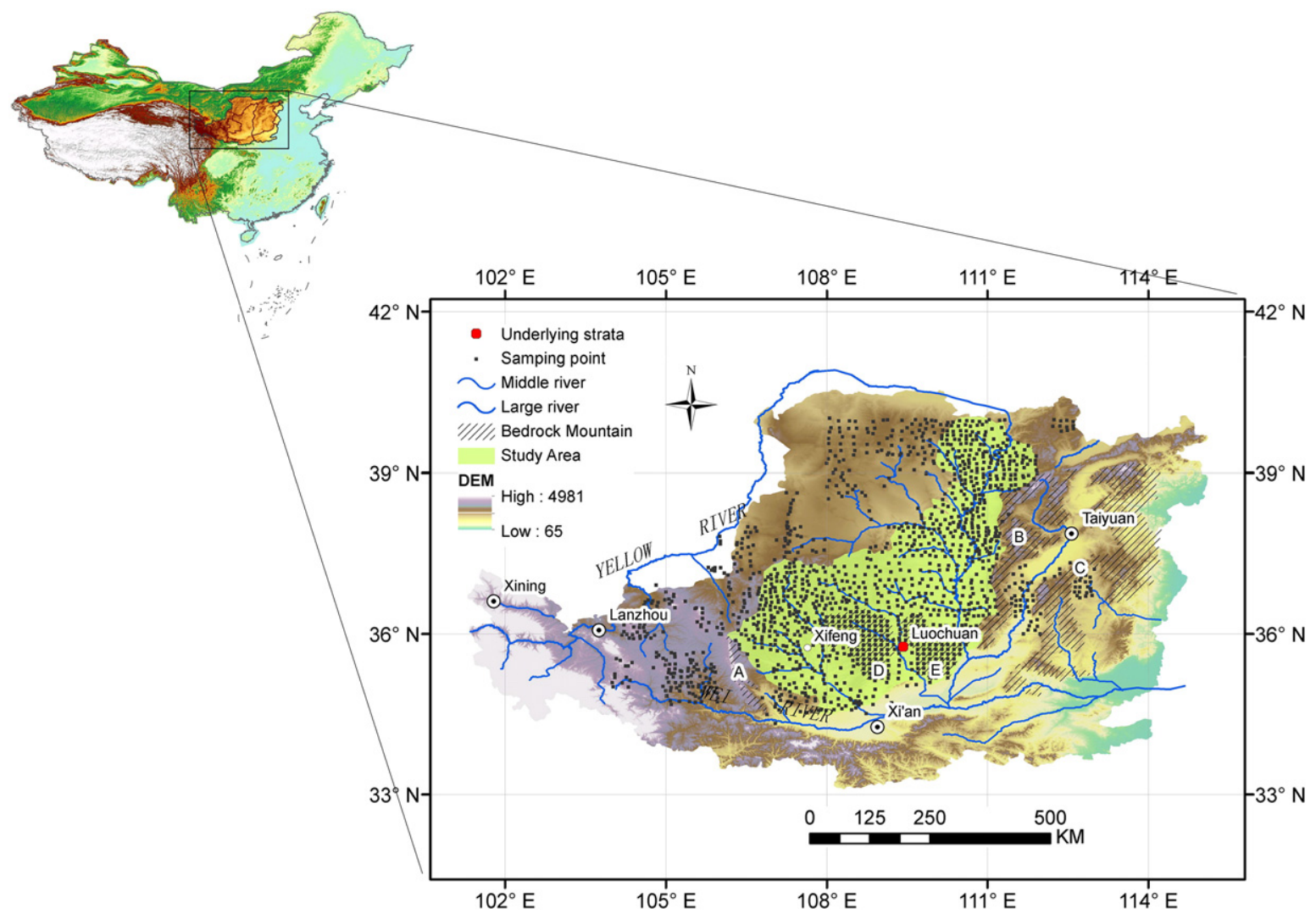

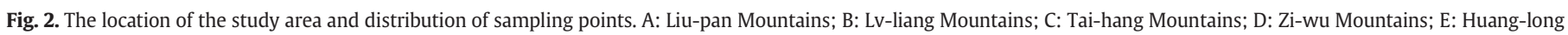
Mountains. The red point shows the location of the section shown in Fig. 1. 

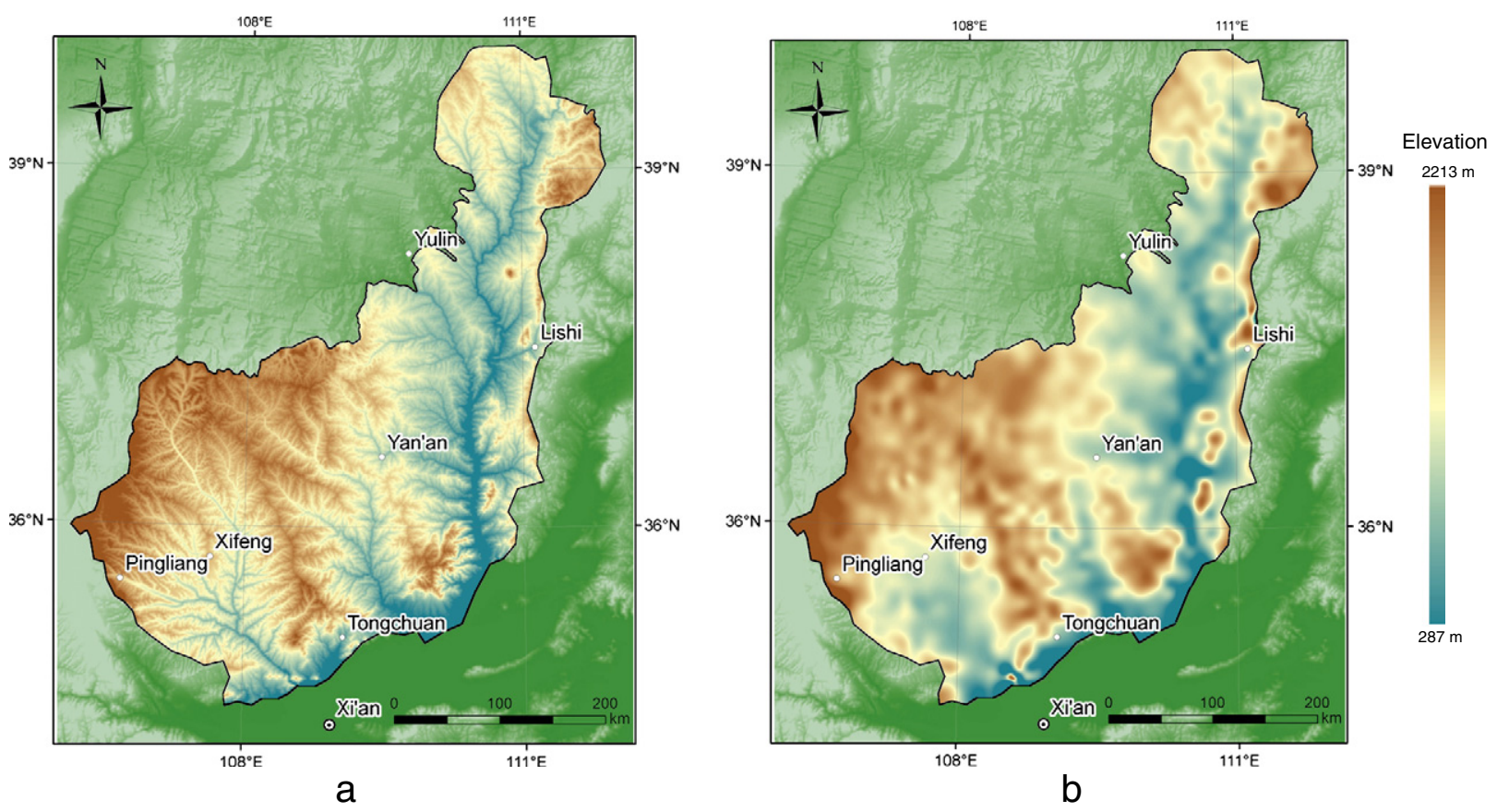

Fig. 3. Comparison of modern and paleotopographic elevations. (a) Modern DEM. (b) Underlying paleotopographic DEM.

In this paper, the paleotopography of the Loess Plateau or the surface of the bedrock below loess deposits is considered in discussing the evolution of the landscape. On the basis of geologic maps, remote sensing (RS) images, digital elevation models (DEMs), and loess thickness data from drilling, we reconstruct the paleotopographic surface. Terrain analysis methods are then adopted to quantify topographic differences between the modern and paleo-surfaces to discuss loess-deposition processes during the Quaternary. A loess thickness map is created to show the spatial distribution of loess deposits. In addition, the geomorphological inheritance, from the underlying paleotopography to the modern terrain, is investigated for different landform divisions.

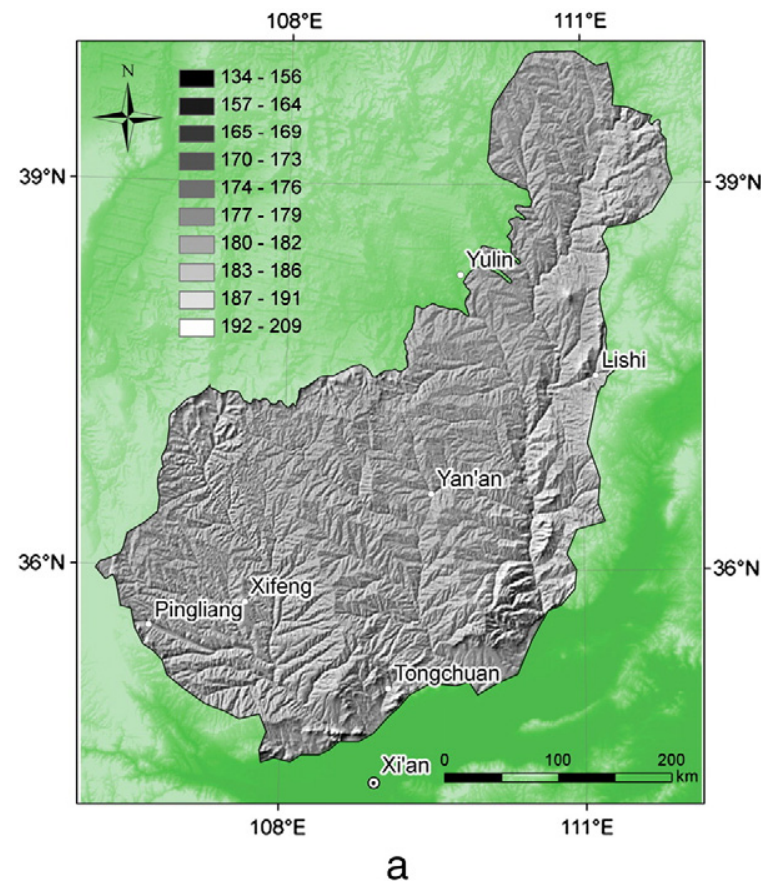

\section{Study area}

The study area (Fig. 2) is a zone of severe soil erosion on the western Loess Plateau (Upper and Middle Yellow River Bureau, 2012), containing the Liu-pan Mountains and the Long-xi Basin in the west, the Tai-hang and Lv-liang Mountains in the east, and the Guan-zhong Basin in the south. The area is located in the tectonically stable Ordos platform (Liu, 1985), with a high density of bedrock outcrops which is suitable for this study. The geo-coordinate of the test area is between $106.4^{\circ}-112.7^{\circ} \mathrm{E}$ and $34.29^{\circ}-40.11^{\circ} \mathrm{N}$, with a total area of $144,190 \mathrm{~km}^{2}$. In the Loess Plateau, there are relatively large mountain ranges such as the Zi-wu and Huang-long Mountains (Li and Lu, 2010), where areas

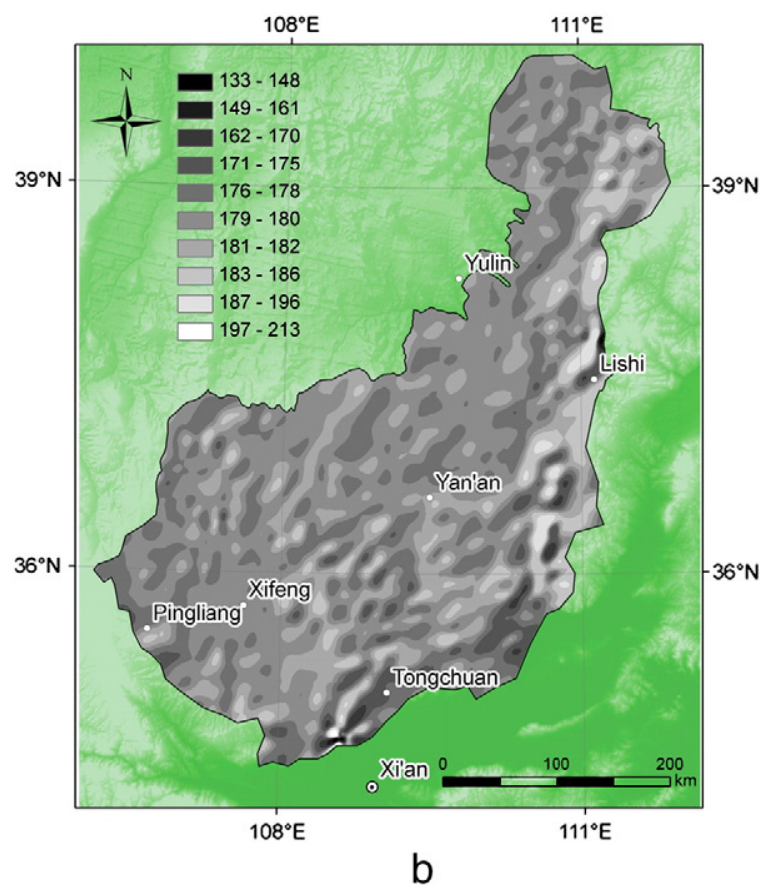

Fig. 4. Comparison of modern and paleotopographic hill-shading texture. (a) Modern terrain. (b) Underlying terrain. 


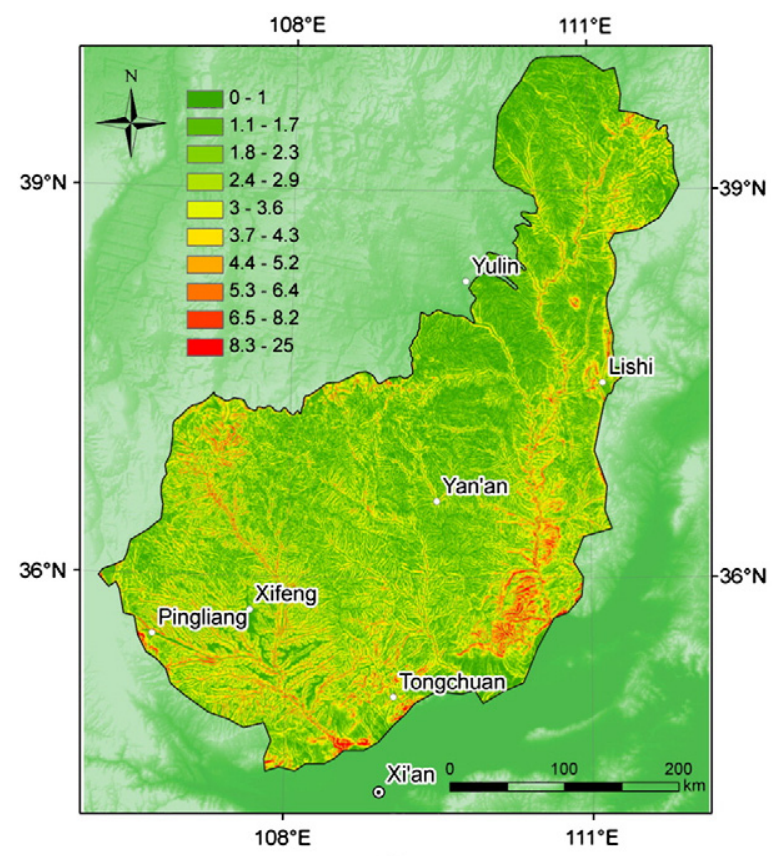

a
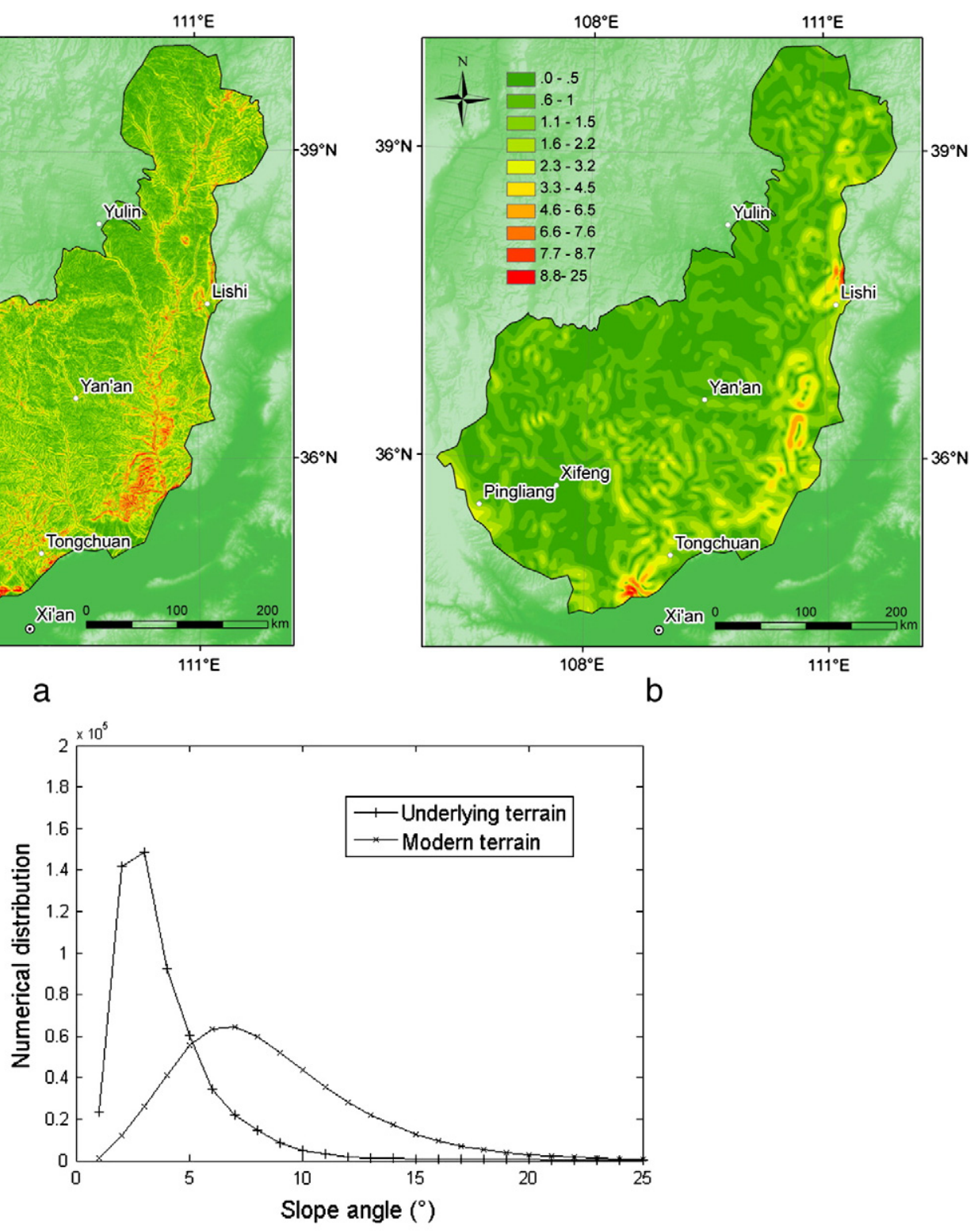

C

Fig. 5. Slope distribution. (a) Modern terrain. (b) Underlying terrain. (c) Slope frequency curves.

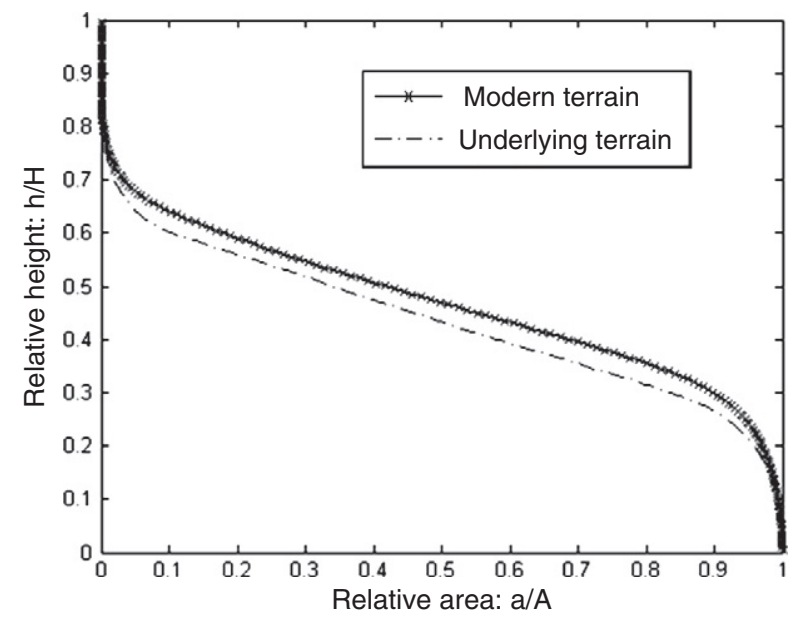

Fig. 6. Hypsometric curves for the modern and underlying terrains. of bedrock strata were not buried during the Quaternary. We included these mountains into the study area but paid attention when dealing with them because unlike other places, not deposition but erosion has been dominant.

The area is mainly characterized by a semi-arid continental monsoon climate, i.e. the East Asian monsoon, which caused the loess dusts from the northwestern desert areas to deposit on the study area during the Quaternary. The annual average temperature ranges from $7{ }^{\circ} \mathrm{C}$ to $12{ }^{\circ} \mathrm{C}$, and the average annual precipitation ranges from 200 to $500 \mathrm{~mm}$. Most rainstorms occur in the summer. The average erosion rate was estimated to be $5000-10,000 \mathrm{t} \mathrm{km}^{-2}$, with the highest up to $30,000 \mathrm{t} \mathrm{km}^{-2}$ (Fu et al., 2011), making it one of the most severe soil erosion regions in the world. The severe soil erosion has brought about significant impact on the ecological security of the Yellow River and its lower reaches. The main vegetation covers are shrubs and grasses, although forests cover the southern part. In general, dry land, accelerated soil erosion and high sediment yields are serious problems in this area. 


\section{Materials and methods}

\subsection{Materials}

The DEM used in this study was derived from the Shuttle Radar Topography Mission (SRTM), an international project to obtain a DEM for a near-global scale from $56^{\circ} \mathrm{S}$ to $60^{\circ} \mathrm{N}$ (Nikolakopoulos et al., 2006; Farr et al., 2007). The spatial resolution of the SRTM data is approximately $90 \mathrm{~m}$ in the Loess Plateau but varies according to location. In order to unify the resolution, all data were resampled using the nearest neighbor method, to obtain a DEM with a cell size of $100 \mathrm{~m}$.

Geologic maps, with a scale of 1:200,000, compiled by the Institute of Geology and Geophysics, Chinese Academy of Sciences, were the source for bedrock outcropping points detected in the study area. Google Earth remote sensing imagery was applied for georeferencing the bedrock outcropping points. The resolution of the available images for the study area was at least $30 \mathrm{~m}$, and they were taken after 2005.

Using loess thickness measured at 167 drilling points, Liu (1985) constructed a loess thickness distribution map of the Chinese Loess Plateau. In this paper, the map and the geological maps showing the Tertiary red clay and earlier strata are used together to reconstruction of the topography buried by loess deposits in more detail.

\subsection{Underlying terrain modeling and loess-deposition process evaluating}

The coordinates and elevations of the points of outcropped bedrock strata were collected from the geologic maps, along with geologic ages (e.g., Tertiary, Cretaceous, and Jurassic) and rock types (e.g., basalt and limestone) via the following steps. First, points where Tertiary bedrock outcrops in channels or valleys were determined using the geologic maps. Second, the position of each point was precisely georeferenced using Google Earth images. Third, the data were combined with the drilling dataset compiled by Liu (1985) to construct a paleotopographic surface model using interpolation. The distribution of the sampling points is shown in Fig. 2, and the location of Fig. 1 is in Luochuan show in Fig. 2. Through a comparison of various interpolation methods (Franke, 1982; Mitas and Mitasova, 1988), spline was determined to be the most suitable for this study because of its high accuracy and relatively low variation. The spline function uses the following formula for surface interpolation:

$S(x, y)=T(x, y)+\sum_{j=1}^{N} \lambda_{j} R\left(r_{j}\right)$

where: $j=1,2, \ldots, N ; N$ is the number of points, $\lambda_{j}$ is the $j$-th coefficient obtained from the solution of a system of linear equations, and $r_{j}$ is the distance from the point $(x, y)$ to the $j$-th point. $T(x, y)$ and $R(r)$ are:

$T(x, y)=a_{1}+a_{2} x+a_{3} y$

$R(r)=\frac{1}{2 \pi}\left\{\frac{r^{2}}{4}\left[\ln \left(\frac{r}{2 \tau}\right)+\mathrm{c}-1\right]+\tau^{2}\left[K_{\mathrm{o}}\left(\frac{r}{\tau}\right)+\mathrm{c}+\ln \left(\frac{r}{2 \pi}\right)\right]\right\}$

where $\tau^{2}$ is the weight; $r$ is the distance between the point and the sample, $K_{\mathrm{O}}$ is the modified Bessel function, $\mathrm{c}$ is a constant, $\mathrm{a}_{1}$ to $\mathrm{a}_{3}$ are coefficients obtained from the solution of a system of linear equations. Among all sampling points, $80 \%$ were used for interpolation, and the rest $20 \%$ were used for determining accuracy.

For both the modern terrain and the paleotopography, terrain texture analysis based on hill shading, morphometric analyses of slope angle, slope aspect, and the hypsometric integral were conducted. Terrain texture of the two surfaces was evaluated using hill-shading based on the DEMs and algorithm of Burrough and McDonnell (1998). A 3rd-order finite different weight method (Burrough and McDonnell, 1998) was used to calculate the slope angle, and the frequency distribution of slope values was also implemented (Tang et al., 2008). In the current study, the slope aspect (Burrough and McDonnell, 1998) was also calculated and a numerical statistical analysis was completed for eight different directions, N, NE, E, SE, S, SW, W and NW, which were classified to investigate the slope aspect changes. The hypsometric curve (Strahler, 1952; Li et al., 1990) illustrates the areaheight relationship and the stage of landform development. The hypsometric integral (HI; Strahler, 1952), a parameter showing the stage of landform development, can be derived from the curve.

The loess thickness and geomorphological inheritance analysis were also implemented to reveal the loess-deposition process. The thickness of loess deposits accumulated in the Loess Plateau during the Quaternary is an unsolved issue in the research on loess landform evolution. The widely used loess thickness map of the middle reaches of the Yellow River (Liu, 1985) demonstrates only a very rough trend because it was from the interpolation of data from 167 loess-drilling points. We added another 1739 data point where loess thickness was measured on outcrops to reconstruct the underlying terrain. The geomorphological inheritance, i.e. the influence of pre-Quaternary underlying terrain on the formation of landforms, was analyzed by plotting the elevation of the modern terrain against the underlying paleotopography. Their relationship can be expressed as a simple linear function

$Y=\mathrm{a}+\mathrm{bX}$

where $X$ is the elevation of the underlying terrain, $Y$ is the elevation of the modern terrain, and $\mathrm{a}$ and $\mathrm{b}$ are coefficients obtained from the linear equations.

\section{Results and discussion}

\subsection{Comparison between modern topography and bedrock paleotopography}

The reconstructed loess-underlying paleotopography is shown in Fig. 3b; Fig. 3a shows the modern DEM for comparison. The RMSE of the interpolation for the paleotopography based on the accuracy assessment using the $20 \%$ of data was $36.5 \mathrm{~m}$, and the relative error was less

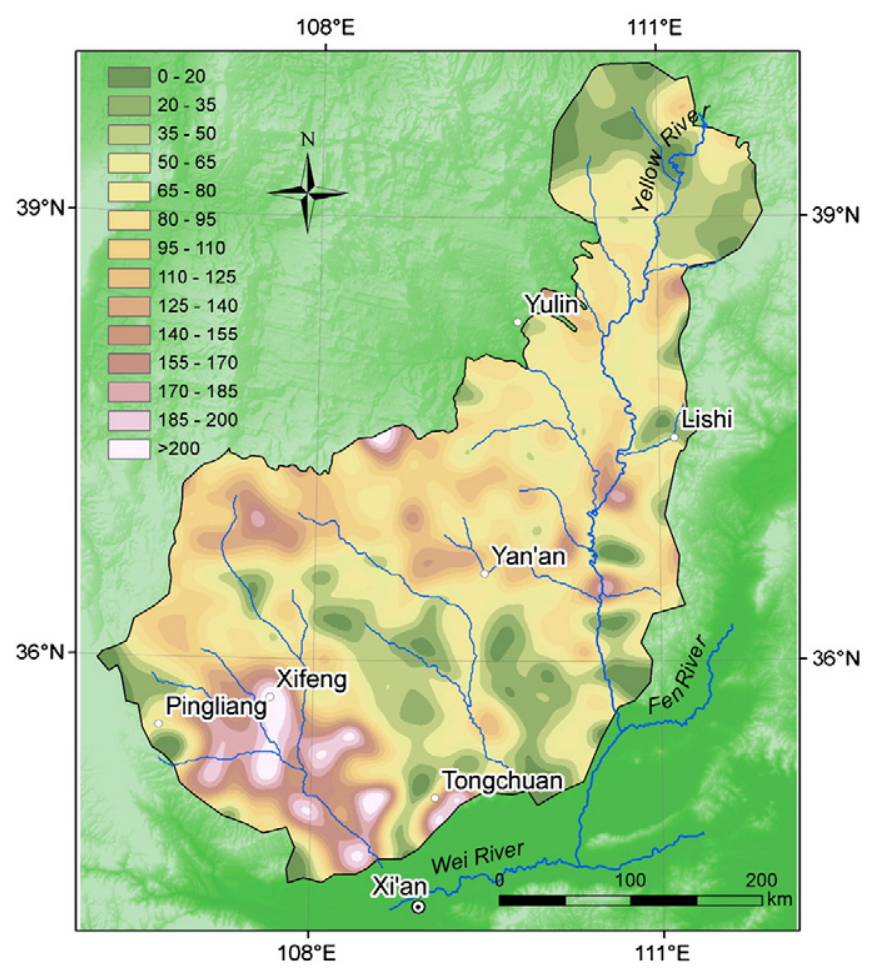

Fig. 7. Loess thickness map of the study area. 


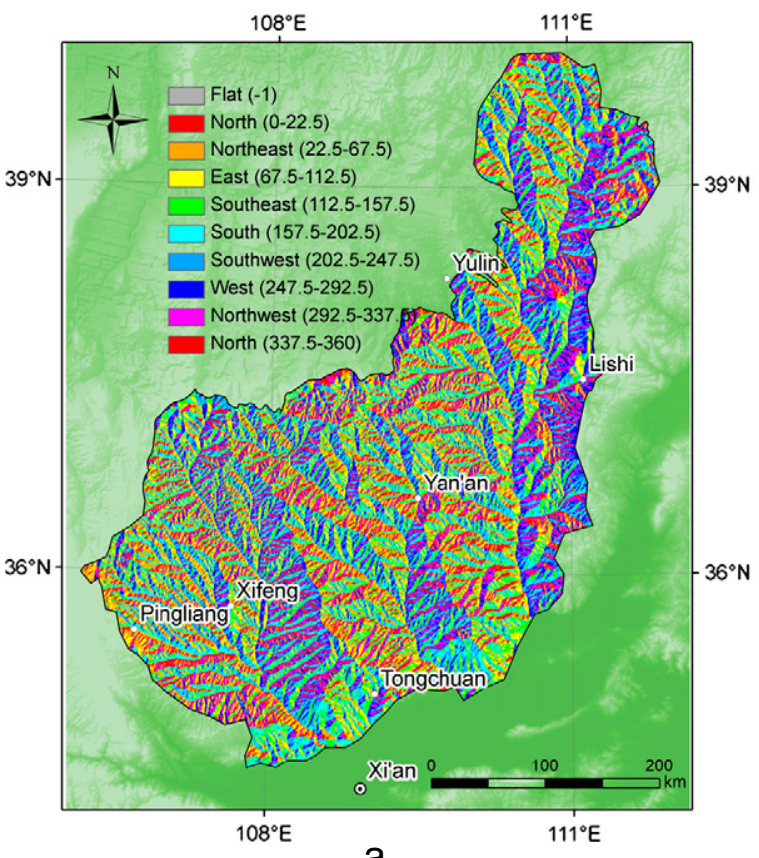

a

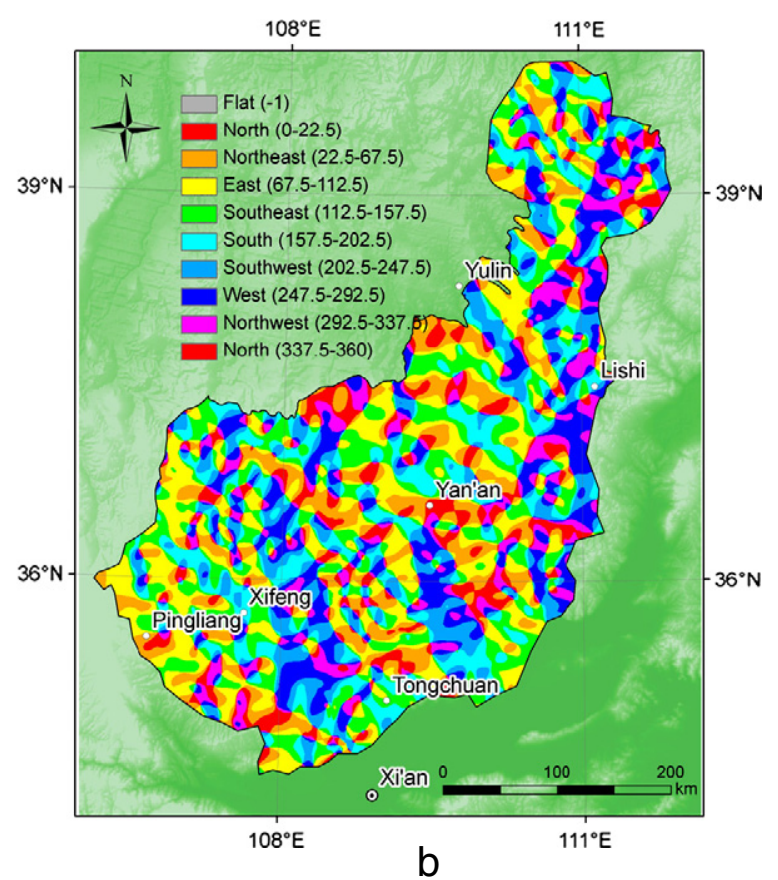

b

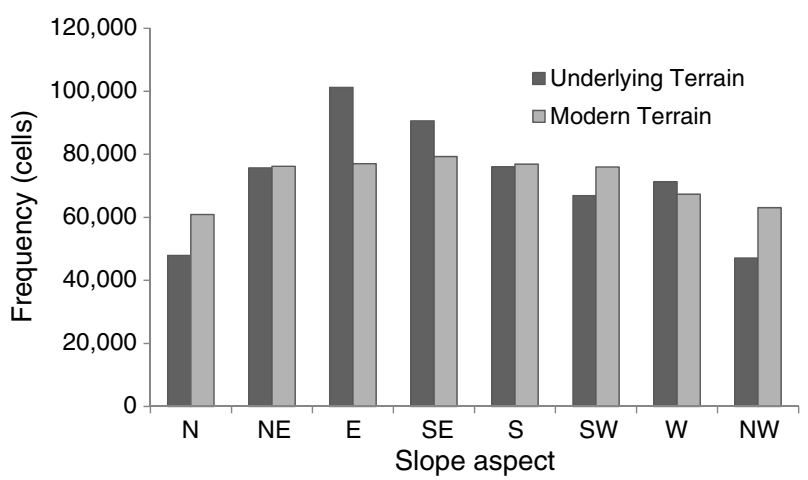

C

Fig. 8. Comparison of modern and paleotopographic slope aspect. (a) Modern terrain. (b) Underlying terrain. (c) Aspect distribution of both terrains.

than $12 \%$, indicating that the paleotopography is accurate enough for general discussion. Significant differences between the modern and paleo-surfaces are found, especially in terms of roughness or smoothness, although their trends such as the distribution of major ridges and valleys show similarities.

The texture of the terrain with hill-shading shows that, the morphology of the reconstructed underlying surface (Fig. 4a) appears much smoother than that of the modern surface (Fig. 4b). Fig. 5 confirms this based on terrain slope computed from the DEMs; the topography of the underground terrain is gentler, more subdued, and less complex. However, this difference seems to reflect the limited topographic expression of the surface interpolated from the limited loess thickness data, although we used a much larger number of data compared to the previous studies. The density of the original data is still far smaller than that used for constructing the DEM of the modern surface.

Fig. 6 shows that the hypsometric curve for the modern terrain is slightly higher but almost parallel to that of the underlying terrain. This shows a significant inheritance of the modern landform for the underlying paleotopography. The HI values for both the modern terrain and the underlying paleotopography are 0.47 and 0.43 , respectively. Therefore, the modern terrain can be considered as less eroded than the underlying terrain, in spite of the more eroded appearance of the former in Figs. 3 to 5. This reflects the thick deposition of loess in the Quaternary. In other words, despite the limited terrain representation of the underlying paleotopography, it can be used to discuss the trend of topographic change due to the loess deposition.

\subsection{Loess thickness distribution}

With a simple mathematical operation for the two terrains, i.e., the height of the modern DEM minus that of the underlying terrain, the

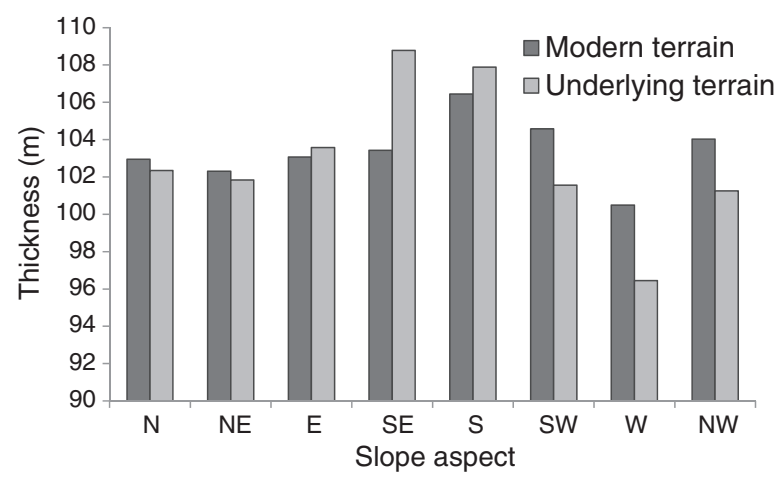

Fig. 9. Loess thickness variation according to slope aspects. 
loess thickness could be determined for the study area (Fig. 7). This gives a more detailed map of the loess thickness distribution in the Loess Plateau compared to the previous studies.

Fig. 7 shows that the loess thickness in the Dong-zhi tableland landform located in the Xifeng area is thicker $(>200 \mathrm{~m})$ than in other places. In addition, despite the many rivers in the study area, the average loess thickness near the rivers was not found to be particularly low. This suggests that the effect of river erosion has been concentrated in narrow zones along the rivers and lateral river erosion has been limited. The average loess deposit thickness was estimated to be $104.6 \mathrm{~m}$, which is close to the known empirical value (Liu, 1985), confirming the applicability of the data we provided in understanding landscape evolution in the Loess Plateau.

\subsection{Characteristics of slope aspect}

There are two theories on the origin of loess deposits in the Loess Plateau: eolian and fluvial (Liu et al., 2001). The slope aspect for both the modern and underlying terrains could indicate the loessdeposition process, because eolian deposition reflects dominant wind directions. The slope aspect was derived for both the underlying and modern terrains (Fig. 8a, b). Fig. 8c summarizes the result, showing that the frequencies of $\mathrm{N}$ and $\mathrm{NW}$ have increased, while those of $\mathrm{E}$ and $\mathrm{SE}$ decreased. This suggests that a large quantity of slopes with $\mathrm{E}$ and SE aspects have been buried or reshaped into those with N and NW aspects. As the data for the modern terrain reflect more of small-scale valleys while those for the underlying terrain are crude, the loess thickness was investigated for each of the eight aspect classes of both terrains (Fig. 9), to check whether the above inference is appropriate. The result show that the thickness for the aspect of underlying terrain tends to be larger for the E- and SE-oriented slopes, and smaller for the N- and NWoriented slopes, supporting the above inference. This result also supports the eolian origin for loess in China, i.e., more loess deposition on the leeward E and SE slopes. The aspects other than E, SE, N and NW show slight changes in the frequency, which may reflect more of the subordinate effect of fluvial processes. However, this issue should be discussed more in detail in the future, because $\mathrm{S}$ - and W-oriented slopes are characterized by rather thick and thin loess deposition, respectively (Fig. 9).

The slope aspect characteristics for both the modern and underlying terrains were found to differ according to the landform divisions made by the Upper and Middle Yellow River Bureau (2012). The division included sub-area I of loess hill-gully (Q1), sub-area II of loess hill-gully (Q2), sub-area $V$ of loess hill-gully (Q5), loess tableland area (Y1, Y2), and bedrock mountain (R) (Fig. 10). The Q1 division, crossed by the middle section of the Yellow River, is characterized by hilly landforms and has suffered from the most serious wind and water erosion in the plateau. The second highest erosion power seems to occur in the Q2 division where typical loess ridge landforms are found. The Q5 division located in the northwestern part of the study area has a rather low average annual precipitation and is dominated by wind erosion. The Y1 division consists of loess tableland landforms located in the southeastern part of the study area, with a North-South oriented shape near the middle section of the Yellow River where severe water erosion occurs. The Y2 division also represents loess tableland landforms but with high thickness of overlying loess, and the $\mathrm{R}$ is the bedrock mountain area with the Zi-wu and Huang-long Mountains. Fig. 11 shows the frequency ratio of slope aspect change from underlying terrain to modern terrain for different landform divisions. The landform divisions of Q1, Q2, Q5 and Y2 appear to have similar trends for all eight aspects, while R and Y1 show apparent differences. This confirms that the loessdeposition process has been limited in the bedrock mountain area, which contains relatively few loess deposits, while the loess tableland area of Y1 located close to the Yellow River, where the loess deposits could be taken away easier by the severe water erosion.

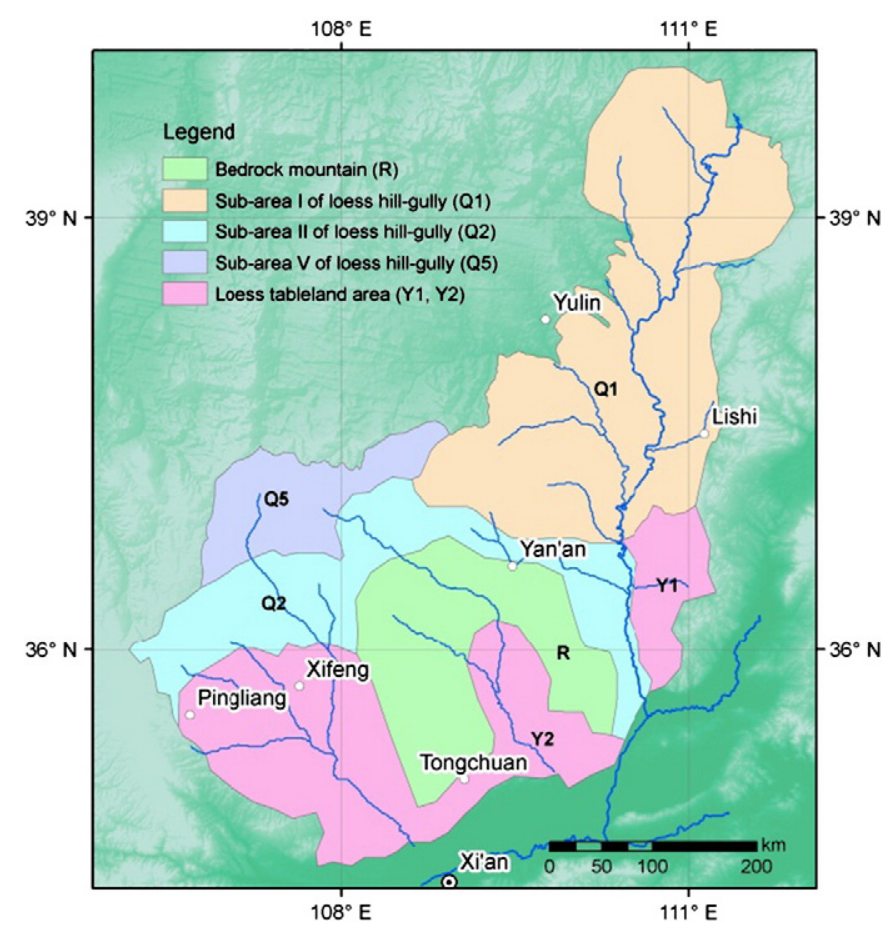

Fig. 10. Landform divisions in the study area.

4.4. Landform inheritance from the underlying terrain to the modern terrain

Fig. 12 shows three inheritance relationships of the modern landform for the underlying paleotopography. i.e. if b of Eq. (4) is unity, both the terrains have comparable relief (ii in Fig. 12); if b > 1, the modern terrain is more fluctuated (iii); and if $b<1$, the modern terrain is less fluctuated (i). According to the constructed plot from 1.57 million elevation point pairs (Fig. 13), a significant linear relationship was obtained: $Y=0.94 X+141.7(r=0.90)$. The b value less than 1 indicates that the modern terrain is less fluctuated than the underlying paleotopography in general, despite the modern terrain data include much more of small valleys and ridges that lead to much higher local slopes than the underlying paleotopography. This, along with the analysis of the hypsometric curves and integrals and the change in slope aspect, confirms the effect of loess deposition.

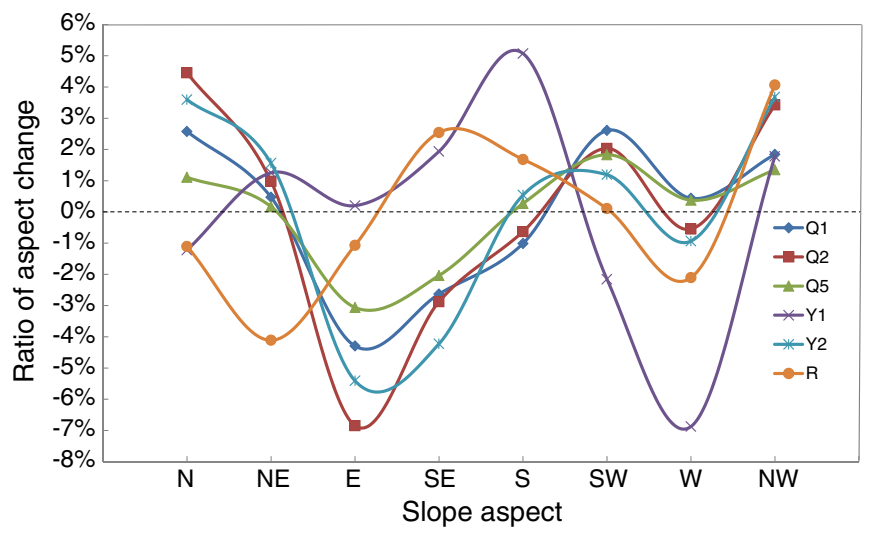

Fig. 11. Ratio of aspect change according to the original aspect for different landform divisions. The ratio of aspect change $(R c)$ is calculated by $R c=(M f-U f) / S u$, where $R c$ is the ratio of aspect change, $U f$ is a slope aspect frequency for underlying terrain, $M f$ is a slope aspect frequency for the modern terrain, and $\mathrm{Su}$ is the number of entire cells in a landform division. The slope aspect along the $\mathrm{X}$-axis is that for the underlying terrain. 


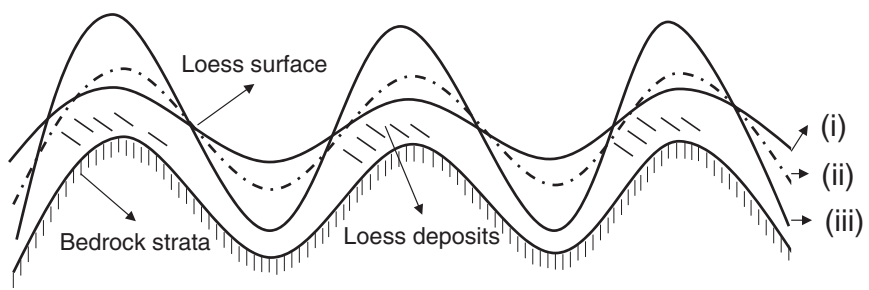

Fig. 12. Different depositional relationships between the modern and underlying terrains. (i) Topographic relief of the modern terrain is more subdued than that of the underlying terrain. (ii) Topographic relief of the underlying and modern terrains are the same. (iii) Topographic relief of the modern terrain is more enhanced than that of the underlying terrain.

In order to reveal spatial differences in loess landform inheritance, Eq. (4) was obtained for each landform division (Fig. 10) except the R division because of its limited loess deposition. The result shown in Table 1 has revealed that the landform inheritance differed significantly according to the divisions. There exists a distinctive characteristic of landform inheritance in the loess hill (Q1) and ridge (Q2) areas ( $b=0.91$ and 0.97 ), as well as the loess tableland area (Y2; $\mathrm{b}=0.92$ ). The Q5 area, located in the northwestern part of the study area, is with strong wind and limited precipitation, which may have led to thicker loess deposition (Fig. 7) and a markedly small value of $b$ $(=0.67)$. The location of the Y1 area is close to the middle reach of the Yellow River, where the loess could be redistributed, which may have resulted in a somewhat smaller value of $\mathrm{b}(=0.86)$.

\section{Conclusions}

We have used comparative analytical methods to simulate the underlying loess terrain and the modern terrain and to reveal the process and mechanism of landscape evolution in the Chinese Loess Plateau. The proposed methods performed well as quantitative descriptors of the formation of loess landforms.

The Ordos platform in China was a bedrock strata terrain in the preQuaternary, but due to more than 2 million years of loess deposition, the morphology of the platform has been reshaped. The hypsometric curve for the modern terrain is higher than and nearly parallel to the underlying terrain with a similar shape and trend, and the XY scatter diagram of the modern and past surface heights demonstrates that the modern terrain is more subdued than the relief of the original underlying paleotopography due to loess deposition. These results depict the characteristics of loess landform evolution. In addition, there are great spatial differences in the geomorphological inheritance according to

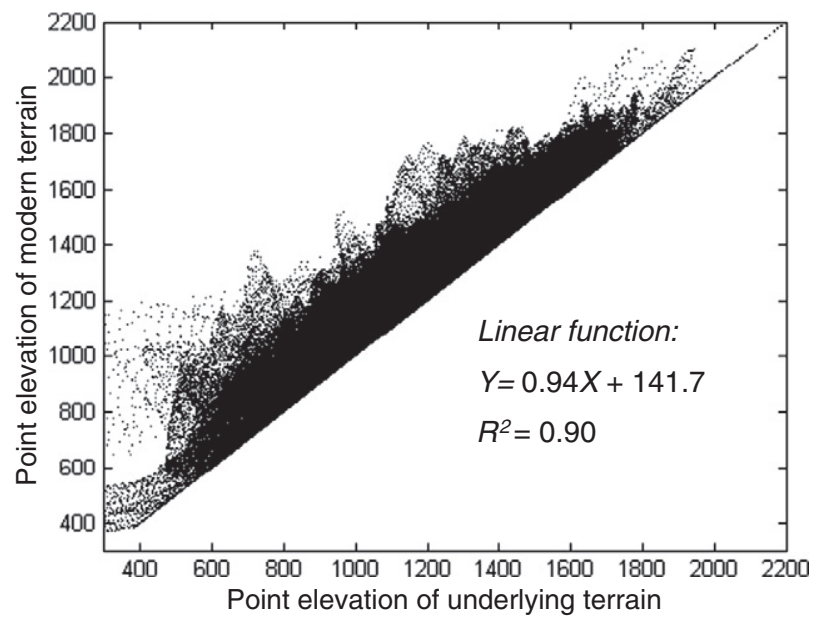

Fig. 13. XY scatter diagram of the elevations of the modern and underlying terrains and the fitted linear function.
Table 1

Parameters of Eq. (4) for different landform divisions.

\begin{tabular}{lllll}
\hline Landform divisions & Slope (b) & Intercept (a) & RMSE & $R^{2}$ \\
\hline Sub-area I of loess hill-gully (Q1) & 0.91 & 169.3 & 58 & 0.89 \\
Sub-area II of loess hill-gully (Q2) & 0.97 & 112.2 & 65 & 0.95 \\
Sub-area V of loess hill-gully (Q5) & 0.67 & 599.7 & 67 & 0.45 \\
Loess tableland area (Y1) & 0.86 & 202.2 & 76 & 0.83 \\
Loess tableland area (Y2) & 0.92 & 196.6 & 100 & 0.80 \\
Entire test area & 0.94 & 141.7 & 77 & 0.90 \\
\hline
\end{tabular}

the loess landform types, although in all divisions the modern terrain is more subdued than the underlying paleotopography. Moreover, the area with the aspects of N and NW has increased significantly, while that of the aspects of E and SE has decreased due to more loess deposition on leeward slopes, supporting the eolian origin for loess in China. The average loess deposit thickness was estimated to be $104.6 \mathrm{~m}$.

The employed methods are found to be useful but can be applied only to macro-scale analyses due to the limited data sampling density. The development of modern geophysical techniques would provide better conditions for the future study of loess landform evolution, because it will enable more precise investigation and modeling. In future work, DEMs representing the surfaces of the Ma-lan, Li-shi and Wu-cheng loess strata (Fig. 1) should be created to deepen the understanding of loess landform development, through a landscape evolution model that integrates the deposition and erosion of the different underlying loess strata.

\section{Acknowledgments}

The research is supported by the National Natural Science Foundation of China (NO. 40930531, 41171320); the Open Foundation of State Key Laboratory of Resources and Environmental Information System (NO. 2010KF0002SA); the National High Technology Research and Development Program of China (NO. 2011AA120303); and the Foundation of Graduate Innovation Plan of Jiangsu Province (NO. CXZZ13_0401). The authors express their gratitude the journal editor Takashi Oguchi and the two reviewers Matthew W. Hughes and Josef Strobl, whose thoughtful suggestions played a significant role in improving the quality of this paper.

\section{References}

Beerten, K., Deforce, K., Mallants, D., 2012. Landscape evolution and changes in soil hydraulic properties at the decadal, centennial and millennial scale: a case study from the Campine area, northern Belgium. Catena 95, 73-84.

Berthling, I., Etzelmüller, B., 2011. The concept of cryo-conditioning in landscape evolution. Quatern. Res. 75, 378-384.

Bowman, D., Svoray, T., Devora, S., Shapira, I., Laronne, J.B., 2010. Extreme rates of channel incision and shape evolution in response to a continuous, rapid base-level fall, the Dead Sea, Israel. Geophys. J. Roy. Astron. Soc. 114, 227-237.

Braun, J., Sambridge, M., 1997. Modelling landscape evolution on geological time scales: a new method based on irregular spatial discretization. Basin Res. 9, 27-52.

Braun, J., Willett, S.D., 2013. A very efficient O(n), implicit and parallel method to solve the stream power equation governing fluvial incision and landscape evolution. Geophys. J. Roy. Astron. Soc. 180-181, 170-179.

Braun, J., van der Beek, P., Valla, P., Robert, X., Herman, F., Glotzbach, C., Pedersen, V., Perry, C., Simon-Labric, T., Prigent, C., 2012. Quantifying rates of landscape evolution and tectonic processes by thermochronology and numerical modeling of crustal heat transport using PECUBE. Tectonophysics 524-525, 1-28.

Burrough, P.A., McDonnell, R.A., 1998. Principles of Geographical Information Systems. Oxford University Press, New York.

Chen, H., Shao, M., Li, Y., 2008. The characteristics of soil water cycle and water balance on steep grassland under natural and simulated rainfall conditions in the Loess Plateau of China. J. Hydrol. 360, 242-251.

Chen, L., Wang, J., Wei, W., Fu, B., Wu, D., 2010. Effects of landscape restoration on soil water storage and water use in the Loess Plateau Region, China. For. Ecol. Manage. 259, 1291-1298.

Cheng, H., Zou, X., Wu, Y., Zhang, C., Zheng, Q., Jiang, Z., 2007. Morphology parameters of ephemeral gully in characteristics hillslopes on the Loess Plateau of China. Soil Tillage Res. 94, 4-14.

Ciampalini, R., Follain, S., Le Bissonnais, Y., 2012. LandSoil: a model for analysing the impact of erosion on agricultural landscape evolution. Geophys. J. Roy. Astron. Soc. 175-176, 25-37. 
Coulthard, T.J., Kirkby, M.J., Macklin, M.J., 2000. Modelling geomorphic response to environmental change in an upland catchment. Hydrol. Process. 14, 2031-2045.

Dymond, J.R., Rose, R.D., 2011. Modelling landscape evolution in the Waipaoa catchment, New Zealand-a phenomenalogical approach. Geophys. J. Roy. Astron. Soc. 132, 29-34.

Egholm, D.L., Pedersen, V.K., Knudsen, M.F., Larsen, N.K., 2012. Coupling the flow of ice, water, and sediment in a glacial landscape evolution model. Geophys. J. Roy. Astron. Soc. 141-142, 47-66.

Farr, T.G., Rosen, P.A., Caro, E., Crippen, R., Duren, R., Hensley, S., Kobrick, M., Paller, M., Rodriguez, E., Roth, L., Seal, D., Shaffer, S., Shimada, J., Umland, J., Werner, M., Oskin, M., Burbank, D., Alsdorf, D., 2007. The Shuttle Radar Topography Mission. Rev. Geophys. 45, RG2004.

Franke, R., 1982. Smooth interpolation of scattered data by local thin plate splines. Comput. Math. Appl. 8, 237-281.

Fu, B., Liu, Y., Lü, Y., He, C., Zeng, Y., Wu, B., 2011. Assessing the soil erosion control service of ecosystems change in the Loess Plateau of China. Ecol. Complex. 8, 284-293.

Fujioka, T., Chappell, J., 2011. Desert landscape processes on a timescale of millions of years, probed by cosmogenic nuclides. Aeolian Res. 3, 157-164.

Hsieh, M.-L., Lai, L.S.-H., Lin, C.D.-J., Shyu, J.B.H., 2012. Late Quaternary landscape evolution and genesis of the 2009 catastrophic landslide in the Hsiao-lin area, southwestern Taiwan. Geophys. J. Roy. Astron. Soc. 179, 225-239.

Hughes, M.W., Almond, P.C., Roering, J.J., Tonkin, P.J., 2010. Late Quaternary loess landscape evolution on an active tectonic margin, Charwell Basin, South Island, New Zealand. Geophys. J. Roy. Astron. Soc. 122, 294-308.

Kaufmann, G., Romanov, D., 2012. Landscape evolution and glaciation of the Rwenzori Mountains, Uganda: insights from numerical modeling. Geophys. J. Roy. Astron. Soc. $138,263-275$.

Lehmkuhl, F., Hülle, D., Knippertz, M., 2012. Holocene geomorphic processes and landscape evolution in the lower reaches of the Orkhon River (northern Mongolia). Catena 98, 17-28.

Li, L.P., Lu, H.Y., 2010. A preliminarily quantitative estimation of the sedimentation and erosion rates of loess deposits in Chinese Loess Plateau over the past 250 ka. Acta Geograph. Sin. 1, 37-52.

Li, Q., Lu, Z.C., Yuan, B.Y., 1990. Quantitative study of the stage of geomorphological evolution. Acta Geograph. Sin. 45, 110-120.

Liu, T., 1985. Loess and Environment. Science Press, Beijing.

Liu, L., Liu, X., 2010. Sensitivity analysis of soil erosion in the northern Loess Plateau. Procedia Environ. Sci. 2, 134-148.

Liu, T., Sun, J., Wu, W., 2001. Past, present and future of the Chinese loess research: a discussion on the reality of facts and myth. Quat. Sci. 3, 185-207.

Maniatis, G., Kurfeß, D., Hampel, A., Heidbach, O., 2009. Slip acceleration on normal faults due to erosion and sedimentation-results from a new three-dimensional numerical model coupling tectonics and landscape evolution. Earth Planet. Sci. Lett. 284, 570-582.

Mitas, L., Mitasova, H., 1988. General variational approach to the interpolation problem. Comput. Math. Appl. 16, 983-992.
Nikolakopoulos, K.G., Kamaratakis, E.K., Chrysoulakis, N., 2006. SRTM vs ASTER elevation products. Comparison for two regions in Crete, Greece. Int. J. Remote Sens. 27, 4819-4838.

Paik, K., 2012. Simulation of landscape evolution using a global flow path search method. Environ. Model. Software 33, 35-47.

Perron, J.T., Kirchner, J.W., Dietrich, W.E., 2009. Formation of evenly spaced ridges and valleys. Nature $460,502-505$

Ravazzi, C., Marchetti, M., Zanon, M., Perego, R, Quirino, T Deaddis, M., De Amicis, M. Margaritora, D., 2013. Lake evolution and landscape history in the lower Mincio River valley, unravelling drainage changes in the central Po Plain (N-Italy) since the Bronze Age. Quat. Int. 288, 195-205.

Refice, A., Giachetta, E., Capolongo, D., 2012. SIGNUM: a Matlab, TIN-based landscape evolution model. Comput. Geosci. 45, 293-303.

Stolte, J., Liu, B., Ritsema, C.J., van den Elsen, H.G.M., Hessel, R., 2003. Modelling water flow and sediment processes in a small gully system on the Loess Plateau in China. Catena 54, 117-130.

Strahler, A.N., 1952. Hypsometric (area-altitude) analysis of erosional topography. Geol. Soc. Am. Bull. 63, 1117-1142.

Tang, G., Li, F., Liu, X., Long, Y., Yang, X., 2008. Research on the slope spectrum of the loess plateau. Sci. China Ser. E: Technol. Sci. 51, 175-185.

Temme, A.J.A.M., Baartman, J.E.M., Schoorl, J.M., 2009. Can uncertain landscape evolution models discriminate between landscape responses to stable and changing future climate? A millennial-scale test. Global Planet. Change 69, 48-58.

Temme, A.J.A.M., Claessens, L., Veldkamp, A., Schoorl, J.M., 2011. Evaluating choices in multi-process landscape evolution models. Geophys. J. Roy. Astron. Soc. 125, 271-281.

Tucker, G.E., Slingerland, R.L., 1994. Erosional dynamics, flexural isostasy, and long-lived escarpments: a numerical modelling study. J. Geophys. Res. 99, 12229-12243.

Tucker, G.E., Lancaster, S.T., Gasparini, N.M., Bras, R.L., Rybarczyk, S.M., 2000. An objectoriented framework for hydrologic and geomorphic modelling using triangulated irregular networks. Comput. Geosci. 27, 959-973.

Upper and Middle Yellow River Bureau, 2012. Atlas of soil and water conservation in the Yellow River Basin. Seismological Press, Beijing.

Willgoose, G., Bras, I., Rodriquez-Iturbe, I., 1991. Results from a new model of river basin evolution. Earth Surf. Proc. Land. 16, 237-254.

Xiong, L., Tang, G., Yan, S., Zhu, S., Sun, Y., 2013. Landform-oriented flow-routing algorithm for the dual-structure loess terrain based on digital elevation models. Hydrol Process http://dx.doi.org/10.1002/hyp.9719.

Xu, X., Zhang, H., Zhang, O., 2004. Development of check-dam systems in gullies on the Loess Plateau, China. Environ. Sci. Pol. 7, 79-86.

Zheng, M., Cai, Q., Cheng, Q., 2008. Modelling the runoff-sediment yield relationship using a proportional function in hilly areas of the Loess Plateau, North China. Geophys. J. Roy. Astron. Soc. 93, 288-301.

Zhu, T., 2012. Gully and tunnel erosion in the hilly Loess Plateau region, China. Geophys. J. Roy. Astron. Soc. 153-154, 144-155. 